\title{
Potential of Xylanase Thermophilic Bacteria in the Pulp Biobleaching Process
}

\author{
Irdawati ${ }^{1 *}$ Nilam Devinda Putri ${ }^{1}$ Syamsuardi ${ }^{2}$ A. Agustien ${ }^{2}$ Y. Rilda ${ }^{1}$
}

\author{
${ }^{1}$ Dept. of Biology, Faculty of Mathematics and Science (FMIPA), Universitas Negeri Padang, Padang, Indonesia \\ ${ }^{2}$ Dept. of Biology, Faculty of Mathematics and Science (FMIPA), Andalas University, Padang, Indonesia \\ *Corresponding author. Email: irdawati.amor40@gmail.com
}

\begin{abstract}
Xylanase enzyme is an extracellular enzyme that has the ability to hydrolyze xylan to xylose. Xylanase can be produced by thermophilic bacteria and is a natural xylanase that is active and stable at high temperatures and alkaline $\mathrm{pH}$, so it has the potential to be used in industrial and biotechnology fields. One industry that utilizes xylanase enzymes is the pulp and paper industry. At present, the pulp bleaching process carried out in Indonesia consists of a bleaching process using chlorine or hydrogen peroxide. The substitution of the use of chlorine with xylanase enzymes is a worthy alternative to reduce the impact caused by the use of chlorine in the pulp bleaching process. This study aims to determine the potential of thermophilic bacterial xylanase enzymes on the brightness of the pulp, and determine the brightness of the pulp at variations in temperature and $\mathrm{pH}$ on pulp fermentation. The pulp is fermented with temperature variations $\left(50^{\circ} \mathrm{C}, 55^{\circ} \mathrm{C}, 60^{\circ} \mathrm{C}, 65^{\circ} \mathrm{C}\right.$, $\left.70^{\circ} \mathrm{C}, 75^{\circ} \mathrm{C}, 80^{\circ} \mathrm{C}\right)$ and $\mathrm{pH}(7 ; 7.5 ; 8 ; 8.5 ; 9 ; 9.5 ; 10)$. The optimum temperature and $\mathrm{pH}$ that produces the lowest kappa number and highest enzyme activity is at $60^{\circ} \mathrm{C}$ and $\mathrm{pH} 8.5$.

Keywords: xylanase enzymes, thermophilic bacteria, pulp, temperature, ph
\end{abstract}

\section{INTRODUCTION}

Indonesia has more than 81 pulp and paper industries which are one of the mainstay industries as sources of foreign exchange. Every year the pulp and paper industry in Indonesia continues to increase. From this condition it can be estimated how much pollution is produced by the pulp industry because of the unavoidable use of chemicals ${ }^{[1]}$. The use of chemicals in the pulp and paper industry occurs in the process of bleaching, namely the process of removing lignin from the pulp is one of the steps to obtain pulp with a more perfect brightness. The bleaching process is usually carried out in stages: the chlorination, extraction and addition of chlorine dioxide. From this stage chlorine plays an important role, while what we know is that chlorine is a toxic material. Discharges from these compounds have a serious impact on the environment, because they are difficult to degrade chemically or biologically so that they can last long on the earth's surface, possibly other can enter into food and will accumulate in the human body or animals that are carcinogenic $^{[2]}$.

The use of enzymes is an alternative to reduce the impact caused by the use of chlorine, and reduce the need for chemicals and increase the strength of pulp and paper ${ }^{[3]}$.One enzyme that is widely used in the pulp and paper industry is xylanase. Xylanase is used in the early stages of bleaching paper pulp, where this enzyme will modify the structure of the fiber by breaking the xylosexylose bond in the xylan chain which results in rupture of the bonds between the remaining lignin and carbohydrates $^{[4]}$.

Research $^{[5]}$ found that xylanase activity produced by Bacillus thermophilic bacteria was able to reduce the use of chlorine by as much as $30 \%$ in the pulp industry. Whereas $^{[6]}$ utilizing Bacillus pumilus in producing xylanase enzymes was also able to reduce the use of chlorine by $17 \%$ for bleaching paper on pulp.

The bleaching process requires high temperature and alkaline $\mathrm{pH}$ and is stable. This potential can be found in thermophilic microorganisms, namely microorganisms that live in high temperatures such as fungi and thermophilic bacteria $^{[6]}$. Xylanase-producing bacteria were obtained from the genera Bacillus and Clostridium ${ }^{[7]}$ and from Bacillus subtilis species ${ }^{[8]}$.

SSA 2 isolates isolated from Sapan River Aro Solok Selatan is one of the thermophilic bacterial isolates capable of producing xylanase enzymes. Based on the research of ${ }^{[9]}$ SSA 2 isolates have a good ability to produce xylanase enzymes to the maximum. This can be seen from the high SSA 2 xylanolytic index compared to other isolates, which is 0.74 .

Xylanase produced by bacteria has resistance at higher temperatures than other organisms and has an optimum $\mathrm{pH}$ that is more diverse on various substrates, which will affect the xylanase enzyme activity produced ${ }^{[4]}$. So it is potential to be used in the process of pre-bleaching paper pulp. This enzyme also has several advantages, which can increase the white degree of the pulp and can reduce the kappa number. Kappa numbers are parameters used to determine the brightness of the pulp or the deliginification of both chemical and semi-chemical pulps that are neither 
white nor half white pulp ${ }^{[10]} \cdot{ }^{[11]}$ stated that the higher the concentration of xylanase enzyme produced in the pulp, the kappa number also decreases, meaning that the brightness level of the pulp is also increasing.

Based on the results of ${ }^{[13]}$ the enzyme is able to work optimally and produce optimum activity under optimal $\mathrm{pH}$ conditions. At optimum $\mathrm{pH}$ conditions, the enzyme has an active side conformation with the substrate so that it can form the right complex of enzymes and produce the product optimally. Besides ph, another factor that influences the catalytic activity of an enzyme is temperature. The catalytic activity of the enzyme will reach its maximum value when conditioned at the optimum temperature of the enzyme where the enzyme is able to work optimally and has a stable active side conformation.

\section{MATERIALS AND METHODS}

\subsection{Material}

The materials used in this study were pulp, $5 \% \mathrm{NaOH}$, Beechwood xylan, Bactereological pepton, yeast extract, K2HPO4, MgSO47H2O, KH2PO4, $0.2 \mathrm{M} \mathrm{CaCl}, \mathrm{H} 2 \mathrm{SO} 4$, Na2S2O3, KMNO4, Amylum, Dinitrosalicylic Acid ( DNS). The thermophilic bacteria used were SSA 2 isolates which were isolated from Sapan Sungai Aro Hot Spring solok selatan.

\subsection{Production of Xylanase Enzymes of Thermophilic Bacteria}

A total of $10 \%(\mathrm{v} / \mathrm{v}$ ) of the thermoxylanolytic bacterial inoculum was inoculated on erlenmeyer containing $100 \mathrm{ml}$ of beechwood xylan media. Then incubated in a shaker with a speed of $150 \mathrm{rpm}$ and a temperature of $60 \mathrm{oC}$ for 6 hours of harvest time.

\subsection{Activation of Pulp using 5\% $\mathrm{NaOH}$}

The 1.7 gr pulp that has been sterilized is then cooked using 5\% NaOH as much as $34 \mathrm{ml}$ in $100 \mathrm{ml}$ Erlenmeyer at $100 \mathrm{oC}$ for 60 minutes. Then the Pulp is separated from $\mathrm{NaOH}$ and rinsed using sterile aquades twice. The rinsed pulp was added with $50 \mathrm{ml}$ of distilled water. Pulp Fermentation in Temperature and $\mathrm{pH}$ Variations Using Xylanase Enzymes of SSA Thermophilic Bacteria 2

The free cell produced from the xylanase of thermophilic bacteria was inserted as much as $5 \mathrm{ml}$ into a $100 \mathrm{ml}$ Erlenmeyer containing $50 \mathrm{ml}$ sterile aquades and pulp cooked with $\mathrm{NaOH}$. Then fermented with temperature variations $(50,55,60,65,70,75$, and $80 \mathrm{oC})$ and $\mathrm{pH}(7$, $7.5,8,8.5,9,9.5$, and 10) for 6 hours, with each control using pulp that has not been added xylanase. Then the enzyme activity was determined using a spectrophotometer with a wavelength of $450 \mathrm{~nm}$

\subsection{Testing of Pulp Brightness by Looking at Kappa Numbers (SII 0530-81).}

Testing of kappa numbers is done by titration. The pulp samples to be tested are dried first in an oven at $100^{\circ} \mathrm{C}$. Drying is done until the water content is zero or it can be said to be a constant pulp weight. Then the pulp sample was weighed as much as 0.5 gr and mashed by scissors. Then put in $1000 \mathrm{ml}$ erlenmeyer and add $350 \mathrm{ml}$ of distilled water. Then in the stirrer for 60 minutes until the pulp decomposes at room temperature $25 \mathrm{oC}$. Then added as much as each $\mathrm{KMNO} 4$ and $\mathrm{H} 2 \mathrm{SO} 412.5 \mathrm{ml}$ (as a rinse of KMNO4) and then wait 3 minutes. Then add $10 \% \mathrm{KI}$ as much as $5 \mathrm{ml}$ until the color changes to light brown, after that the starch is dropped 3-4 drops to blackish blue, and finally titrated with $\mathrm{Na} 2 \mathrm{~S} 2 \mathrm{O} 31 \mathrm{~N}$ (Thiosulfate) until the color becomes violet. Then calculate the amount of $\mathrm{Na} 2 \mathrm{~S} 2 \mathrm{O} 3$ solution used so that the lavender color, then the numbers obtained are entered into the kappa number formula. However, the form has been prepared previously with the same steps as above but does not use pulp. Kappa number calculation formula:

Kappa number $=(\mathrm{b}-\mathrm{a}) \mathrm{N} \times 10$

$\mathrm{W}$

Description:

$\mathrm{b}=$ Volume of titration Blank $(\mathrm{ml})$

$\mathrm{a}=$ Volume of titration Sample (ml)

$\mathrm{W}=$ Sample Weight (gr)

$\mathrm{N}=$ Standardization of $\mathrm{Na} 2 \mathrm{~S} 2 \mathrm{O} 3(0,11053)$

\section{RESULT AND DISCUSSION}

Potential of Thermophilic Bacteria Xylanase Enzyme Against Pulp Brightness

The use of xylanase enzymes from South Solok SSA2 isolates as pulp additives obtained data as in Figure 1. Free cell enzymes show lower kappa numbers than controls (pulp without xylanase enzyme). his indicates that the fermentation process using bacterial cells can be applied as a pulp additive because it can clear the pulp by reducing kappa numbers, and has the opportunity to be used as a substitute for chlorine bleach which is harmful to the environment. 


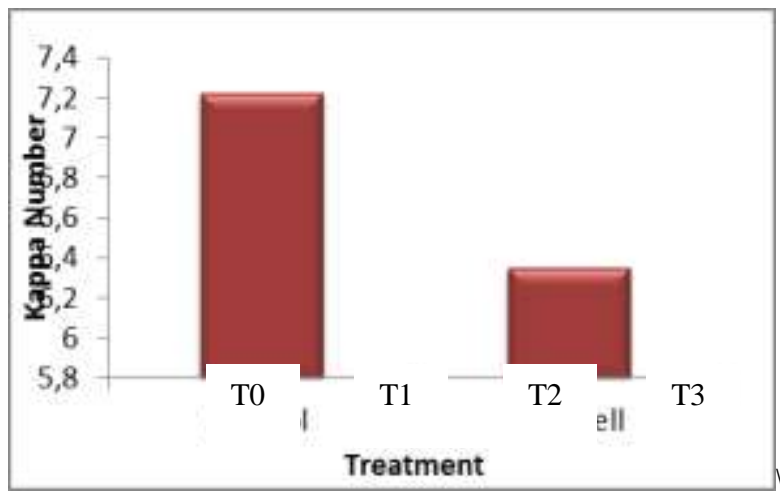

Figure 1. Kappa Numbers in Control and Free Cells

Based on the figure above it is known that pulp treated with free cells has a maximum brightness level than pulp without using free cell xylanase. The low kappa number indicates the whiteness of the pulp (brightness) because xylanase has been able to break the xylan bond with lignin. [13] explained that the bleaching process in the pulp industry, namely the process of removing lignin from pulp is one of the stages to obtain pulp with a more perfect level of brightness. The action of xylanase in the bleaching process is breaking the xylose-xylose bond in the xylan chain so that the bond between the remaining lignin and carbohydrate breaks. This means that xylanases act as enzymes that facilitate the transfer of lignin to the pulp bleaching process.

The results of $[11,3]$ concluded that the difference in brightness between the pulp treated with xylanase without xylanase administration, because the addition of enzymes can cause changes in the formation of cellulose chain hydrogen bonds so that it allows the release of lignin easily, so the color the pulp will be whiter. Pulp fibers after xylanase administration have greater porosity, bubbling, and loss of density in microfibyl pulp. The thinner-walled pulp fiber with a smoother surface and fiber diameter increases significantly. The results of [14] also stated that the pulp given the xylanase enzyme could increase the brightness of the pulp compared to the control without xylanase.

Effect of Temperature on the Biobleaching Pulp Process The increase in the degree of brightness in the bleaching process in pulp with the xylanase (biobleaching) enzyme in this study was influenced by temperature. Based on the results obtained that the optimum temperature for pulp fermentation is at $60^{\circ} \mathrm{C}$. This is marked by the value of the enzyme activity and the kappa number obtained.

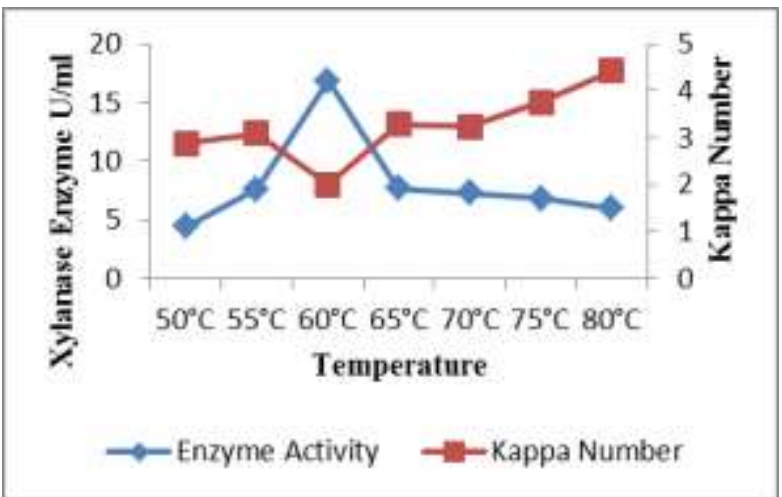

Figure 2. Effect of Temperature on the Biobleaching Pulp Process

At a treatment temperature of $60^{\circ} \mathrm{C}$ is able to produce the highest enzyme activity and can increase the production of the enzyme xylanase more so that the brightness of the pulp in the pulp fermentation process is also higher. This is proven by the low kappa number obtained which is 1,989 and high enzyme activity that is 16,827 compared to other temperature variations.

[15] says that enzyme activity will increase with increasing temperature until the optimum temperature is reached. An increase in temperature above the optimum temperature will cause enzyme activity to decrease due to denaturation of xylanase due to disruption of the active side of the enzyme, so the enzyme does not work properly. However, at a temperature of $65^{\circ} \mathrm{C}$ to $80^{\circ} \mathrm{C}$ the brightness of the pulp decreases because the enzyme activity under conditions that are too high will decrease and denaturate so that the production of xylanase enzymes in the pulp fermentation process is also reduced. This causes the brightness in the pulp also decreases, as evidenced by the high kappa number obtained which is 4,420 at $80^{\circ} \mathrm{C}$. According to[10] kappa number is a parameter used to determine the brightness level of pulp or deliginification of chemical and semi-chemical pulp both pulp that has not been white or half white. [11] states that the higher the concentration of xylanase enzymes produced in the pulp, the kappa number also decreases, meaning the level of brightness in the pulp also increases.

Enzyme activity will reach its maximum value when it is conditioned at the optimum enzyme temperature at which the enzyme is able to work optimally and has a stable active side conformation[12]. Determination of the optimum temperature of enzyme activity is very necessary in the application of an enzyme, because at temperatures that are too low the stability of the enzyme is high but the activity is low, whereas at temperatures that are too high the activity is high but the stability is low[16]. Optimum temperature conditions will support the enzyme to catalyze a reaction well. While the temperature is not appropriate will cause damage or inactivity of proteins in an enzyme so that the function and activity of the enzyme is reduced.

Effect of $\mathrm{pH}$ on the Biobleaching Pulp Process

$\mathrm{pH}$ is one of the factors that affect xylanase production in the pulp fermentation process. As shown in Figure 2. 


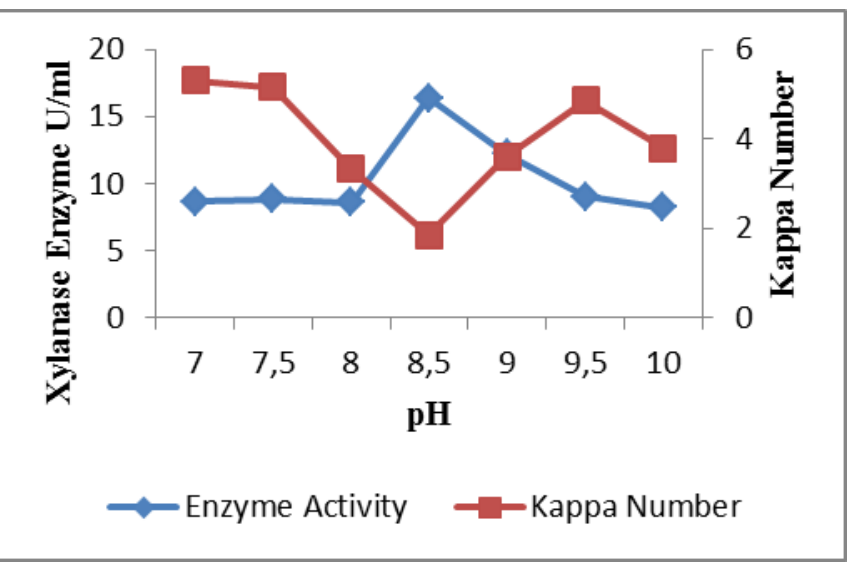

Figure 3. Effect of $\mathrm{pH}$ on the Biobleaching Pulp Process

Based on Figure 3 it can be seen that at $\mathrm{pH} 7 ; 7.5$ and 8 have almost the same enzyme activity value in producing xylanase which is 8,$629 ; 8,810$ and $8.567 \mathrm{U} / \mathrm{ml}$ and experienced an increase in enzyme activity at $\mathrm{pH} 8.5$, with a value of $16.381 \mathrm{U} / \mathrm{ml}$. Whereas at a $\mathrm{pH}$ that is too high, $\mathrm{pH} 9 ; \mathrm{pH} 9.5$ and $\mathrm{pH} 10$ of xylanase enzyme production decreased with the value of xylanase enzyme activity that

\section{CONCLUSION}

Based on research that has been done, xylanase enzymes derived from thermophilic bacterial SSA 2 isolates have the potential for pulp brightness. at a temperature of $60^{\circ} \mathrm{C}$ and $\mathrm{pH} 8.5$ was able to produce the highest enzyme activity ie 16,827 $\mathrm{U} / \mathrm{ml}$ and $16,381 \mathrm{U} / \mathrm{ml}$. And the lowest kappa number is 1.989 at $60^{\circ} \mathrm{C}$ and 1.842 at $\mathrm{pH}$ 8.5. This means that the temperature is $60^{\circ} \mathrm{C}$ and $\mathrm{pH} 8.5$ is the optimum temperature and $\mathrm{pH}$ to get the highest enzyme activity and the highest brightness level of the pulp which is indicated by the low kappa number.

\section{REFERENCES}

[1] Haroen, W.K. dan T. Artiningsih. 2004. Penggunaan enzim polyporaceae pada pemutihan pulp kraft Acacia mangium. Prosiding Seminar MIPA IV, Institut Teknologi Bandung. Bandung: 347-351.

[2] Valchev, I. and P. Tsekova. 2010. Xilanase Posttreatment as a Progress in Bleaching Processes. Apita Journal .63(1): 53-56.

[3] Cheng, X., Chen, G., Huang, S., Liang, Z. 2013. Biobleaching Effects of Crude Bioresouces. 8(4), 6424-6433.

[4] Beg, Q. K., M. Kapoor, L. Mahajan and G.S. Hoodal. 2001. Microbial xylanases and their industrial applications: A Review. Applied is 12,$183 ; 8,997$ and 8,177 . Based on these results $\mathrm{pH} 8.5$ is the optimum $\mathrm{pH}$ for producing xylanase in the biobleaching process of pulp compared to other $\mathrm{pH}$ variations. This shows that SSA2 thermophilic bacteria is classified as alkalophilic.

${ }^{[12]}$ said that at optimum $\mathrm{pH}$ conditions, enzymes have active side conformations that are compatible with the substrate so that they can form the right substrate enzyme complex and produce the maximum product. Conversely, at less optimal $\mathrm{pH}$ conditions, the enzyme will undergo conformational changes that cause the enzyme to undergo structural changes and lose its activity. This is also evidenced by the high production of xylanase at $\mathrm{pH} 8.5$ and the maximum brightness level of the pulp is characterized by the low kappa number obtained during the pulp fermentation process, which is 1,842 compared to controls that have the highest kappa number, 7,226 and 6,132 U enzyme activity / $\mathrm{ml}$.

microbiology and biotechnology 56 (3-4): 326338.

[5] Kiddinamoorthy, J., A. J. Anceno. 2008. Production, purification and characterization of Bacillus sp. GRE7 xilanase and its application in eucalyptus Kraft pulp biobleaching. World Journal of Microbiology and Biotechnology 24(5): 605612.

[6] Garg, G., R. Mahajan. 2011. Xilanase production using agro-residue in solid-state fermentation from Bacillus pumilus ASH for biodelignification of wheat straw pulp. Biodegradation. 22 (6): 114354.

[7] Trismilah, T. and D. R. Waltam. 2016. "Produksi Xilanase Menggunakan Media Limbah Pertanian dan Perkebunan. " Jurnal Teknologi Lingkungan 10(2): 137-144.

[8] Annamalai, N., Thavasi, R., Jayalakshmi, S., and Balasubramanian, T. 2009. Thermostable and alkaline tolerant xylanase production by Bacillus subtilis isolated from marine environment. Indian Journal of Biotechnology. 8: 291-297.

[9] Irdawati., Syamsuardi., A. Agustien., and Yetria Rilda. 2018. Screening of Thermophilicbacteria Produce Xylanase from Sapan Sungai Aro Hot Spring South Solok. Materials Science and Engineering. 335

[10] McDonough, T.J., Shunichiro uno, Alan W. Rudie, and Charles E. Courchene. 2009. Optimization of ECF Bleaching of Kraft Pulp: II. Effects of Acid Prehydrolysis on Hardwood Pulp Bleachability. Tappi Journal. 
[11] Golaguri, B. R., C. Thulluri. 2012. Potential of Thermo andal., kali Stable Xilanasees From Thielaviopsis basicola (MTCC-1467) in Biobleaching of Wood kraft Pulp. Applied Biochemistry and Biotechnology. 167(8): 2369-80.

[12] Habibie, F. M. 2014. Isolasi dan Identifikasi Molekuler Mikroorganisme Termofilik Penghasil Xilanase dari Lumpur Lapindo.Jurnal Pangan dan Agroindustri. Vol. 8(1) Hal: 231-238.

[13] Bajpai, P. 2004. Biological Bleaching Of Chemical Pulps. Critical Reviews In Biotecnology 24(1):1-58.

[14] Irdawati. 2019. Keanekaragaman Bakteri Thermoxilanolitik dari Habitat Air panas Solok Selatan dan Potensinya Sebagai Aditif Pulp. Disertasi. Pasca Sarjana Universitas Andalas. Padang.

[15] Widhiana, E. T., P. Ardiningsih dan Lia Destiarti. 2015. Produksi dan Karakterisasi Xilanase dari Jamur Xilanolitik Asidofilik. Jurnal JKK. Vol 4 (2) Hal: 44-49.

[16] Muawanah, A. 2006. Produksi Enzim Xilanase Termostabil dari Thermomyces lanuginosus IFO 150 pada Substrat Bagasse Tebu. Tesis. Bogor: Institut Pertanian Bogor. 